\title{
Gynura procumbens Leaf Improves Blood Glucose Level, Restores Fertility and Libido of Diabetic-Induced Male Rats
}

(Daun Gynura procumbens Meningkatkan Aras Glukosa Darah serta Memulihkan Kesuburan dan Libido Tikus Jantan Aruhan Diabetik)

\author{
KHAIDATUl AKMAR KAMARUZAMAN \& MAHANEM MAT NOOR*
}

\begin{abstract}
Gynura procumbens (GP) has been widely used in traditional medicine due to its ability in treating various types of diseases. This study was carried out to determine the effects of GP on blood glucose level, fertility and libido of streptozotocin-induced male rats. A total of 42 male rats were randomly sorted into six groups; normal, negative and positive controls and three treated groups with different dosages of GP aqueous extract (GPAE); 150, 300 and $450 \mathrm{mg} / \mathrm{kg}$. Each group was treated via oral feeding for 14 consecutive days. The rats were sacrificed on day 15 for further analysis. Administration of GPAE significantly lowered the fasting blood glucose (FBG) level and increased the plasma testosterone level of diabetic-induced rats compared to the positive and negative control groups. There was also a significant increase in the sperm quality as well as the fertility of GPAE treated groups compared to the negative and positive control groups. Sexual behaviour analysis demonstrated that GPAE is able to facilitate the expression of sexual behaviour significantly; increased mounting frequency and reduced mounting latency. These lines of evidence suggested that GPAE can act as antihyperglycaemic, profertility and libido agents. However, its mechanism(s) remains unresolved.
\end{abstract}

Keywords: Diabetic; fertility; Gynura procumbens; sexual behaviour; testosterone

\section{ABSTRAK}

Gynura procumbens (GP) telah digunakan secara meluas dalam perubatan tradisional kerana keupayaannya dalam merawat pelbagai jenis penyakit. Kajian ini telah dijalankan untuk menentukan kesan GP ke atas aras glukosa darah, kesuburan dan libido tikus jantan yang diaruh streptozotocin. Sejumlah 42 ekor tikus jantan telah diasingkan secara rawak kepada enam kumpulan; kawalan normal, negatif dan positif serta tiga kumpulan yang dirawat dengan dos berbeza ekstrak akues GP (GPAE); 150, 300 dan $450 \mathrm{mg} / \mathrm{kg}$. Setiap kumpulan diberi perlakuan secara oral selama 14 hari berturut-turut. Tikus dikorbankan pada hari ke-15 untuk analisis lanjut. Perlakuan GPAE dengan signifikan telah menurunkan tahap glukosa darah berpuasa (FBG) dan meningkatkan aras testosteron plasma tikus diaruh diabetes berbanding dengan kumpulan kawalan positif dan negatif. Terdapat juga peningkatan signifikan dalam kualiti sperma serta kesuburan kumpulan rawatan GPAE berbanding dengan kumpulan kawalan negatif dan positif. Kajian kelakuan seksual menunjukkan bahawa GPAE ini dapat meningkatkan kelakuan seksual dengan signifikan; meningkatkan kekerapan pemanjatan dan mengurangkan tempoh pendam pemanjatan. Bukti ini mencadangkan bahawa GPAE boleh bertindak sebagai agen anti hiperglisemik, prokesuburan dan libido. Walau bagaimanapun mekanisme ini masih belum diketahui.

Kata kunci: Diabetis melitus; Gynura procumbens; kelakuan seksual; kesuburan; testosteron

\section{INTRODUCTION}

Diabetes mellitus is a metabolic disorder caused by the inability to produce or secrete insulin that results in hyperglycaemia. It is often associated with reproductive health problems such as sexual dysfunction, impotence and fertility. The statistics are increasing globally and thus raised concerns among researchers. Synthetic drugs have been commonly used in conventional medication to reduce the blood glucose level in patients. However, the use of synthetic drugs is likely to give serious long term effects. This has lead researchers to study the benefits of medicinal plants in treating diabetes mellitus.
The government has been focusing on medicinal plants or herbs as an alternative therapeutic treatment option because it is safer. A large number of medicinal plants and their extracts have shown beneficial therapeutic effects. Interestingly, some plants such as Gynura procumbens have the ability to cure diabetes as well as infertility.

Gynura procumbens is also known as sambung nyawa in Malay. It has been widely used in South East Asia namely Indonesia, Malaysia and Thailand as a traditional treatment of many ailments. A study has shown that Gynura procumbens is able to treat eruptive fevers, rash, kidney diseases, migraine, constipation, hypertension, diabetes 
mellitus and cancer (Perry 1980). Akowuah et al. (2002) found that the leaves of Gynura procumbens have bioactive compounds such as flavonoids, saponins, tannins and terpenoids.

Previous studies have demonstrated the effectiveness of Gynura procumbens as a natural antihyperglycaemic agent. Zurina et al. (2010) reported that different methods of plant extraction resulted in different outcome. It was found that $25 \%$ ethanolic extract of Gynura procumbens gave the best result in reducing blood glucose level. It was also found that the Gynura procumbens extract mimics the metformin mechanism (Algariri et al. 2013) by increasing the glucose intake in the muscle cells (Zurina et al. 2010). However, its potential in fertility on diabetic subjects remains hardly known. Mahanem Mat Noor and Nani Rahayu (2012) showed that Gynura procumbens methanolic extract is able to improve sperm quality. The increase in sperm count indicates that this plant promotes the process of spermatogenesis in the testes.

Hence, the aim of this study was to assess the antidiabetic activity of Gynura procumbens aqueous extract (GPAE) and its potential in the recovery of reproductive system of streptozotocin-induced diabetic male rats

\section{MATERIALS AND METHODS}

\section{PREPARATION OF GYNURA PROCUMBENS AQUEOUS EXTRACT (GPAE)}

Fresh leaves of Gynura procumbens were collected from the Plant House at Universiti Kebangsaan Malaysia (UKM), Selangor. The leaves were dried in the oven for $72 \mathrm{~h}$ at $48^{\circ} \mathrm{C}$ and were powdered afterwards. The powdered herb was then mixed with distilled water with a ratio of 1:20 in a water bath for three hours at $60^{\circ} \mathrm{C}$. The extract was then filtered and freeze-dried (Büchi Rotovapor ${ }^{\circledR}$ R-200/205); yielding brown powder extract. The extract was kept refrigerated to maintain its freshness.

\section{INDUCTION OF DIABETES}

Diabetes was induced by a single intravenous injection of streptozotocin (STZ) with a dose of $50 \mathrm{mg} / \mathrm{kg}$ at the root of the rat's tail after fasting overnight. The STZ was dissolved in a sodium citrate buffer at $\mathrm{pH} 4.5$. The fasting blood glucose (FBG) level of the rats was determined using Glucometer Accucheck Active ${ }^{\circledR}$ Roche Diagnostic (Canada) after seven days of induction. Blood glucose level that elevated $13 \mathrm{mmol} / \mathrm{L}$ was considered diabetic.

\section{ANIMAL HUSBANDRY AND TREATMENTS}

A total of 42 male rats aged 8 weeks (120-200 g) were obtained from the Animal House at Universiti Kebangsaan Malaysia (UKM), Selangor. All animals were acclimatized to the experimental condition one week prior to experiment. All rats were fed with standard pellet diet and allowed ad libitum access to water. The rats were kept in PVC cages at controlled room temperature with $12 \mathrm{~h}$ light- $12 \mathrm{~h}$ dark cycle.

The male rats were randomly sorted into six groups with seven rats in each group. Five groups were induced with STZ in which three of the groups were treated with GPAE at different dosages; 150, 300 and $450 \mathrm{mg} / \mathrm{kg}$, respectively. One group was treated with $500 \mathrm{mg} / \mathrm{kg}$ of metformin, an established antidiabetic drug which served as the positive control, and the other group remained untreated and acted as the negative control. Another group left served as the normal control group. Each group was treated for 14 consecutive days via oral feeding method. This study was approved by the Animal Ethics Committee of Faculty of Medicine, Universiti Kebangsaan Malaysia (FST/2013/MAHANEM/31-JAN./492-FEB.-2013-FEB.-2015).

\section{SPERM QUALITY ANALYSIS (SPERM COUNT,} MOTILITY, MORPHOLOGY AND VIABILITY)

The rats were sacrificed and the cauda epididymis was removed to obtain the sperm samples. The caudal epididymis was minced and suspended in the BiggersWhitten-Whittingham medium (Biggers et al. 1971). The samples were then incubated in $5 \% \mathrm{CO}_{2}$ incubator for 30 min at $37^{\circ} \mathrm{C}$ to allow the sperm to swim up. The sperm sample quality was assessed based on the parameters: sperm count, motility, morphology and viability. The sperm samples were assessed according to the WHO laboratory manual (2010).

\section{TESTOSTERONE HORMONE ANALYSIS}

Blood samples were collected from all groups through cardiac puncture for estimation of serum testosterone level using a commercial kit. The samples were assessed as per manufacturer's manual (Testosterone EIA kit by Cayman Chemical Company).

\section{SEXUAL BEHAVIOUR TEST}

Sexual behaviour test was done to determine the effect of GPAE on rats after 14 days of treatment. The test was performed according to the rat sexual protocol proposed by Agmo (1997). Healthy female rats were used in this study and made receptive for sexual activity test by subcutaneous injections of $20 \mu \mathrm{g} /$ rat of estradiol benzoate (52 $\mathrm{h}$ prior to mating) and $1 \mathrm{mg} /$ rat of progesterone $(4 \mathrm{~h}$ earlier before mating). The animals were adapted to the laboratory conditions for $10 \mathrm{~min}$ before the test. A male rat was placed in the test cage for the first $5 \mathrm{~min}$ and then followed by the female rat. The observation period was within 15 min. Sexual behaviour was determined by observing the mounting frequency (number of mounting occurred) and mounting latency (the time when the first mounting occurred).

\section{FERTILITY TEST}

Fertility test was done to study the effect of GPAE on mating outcome and sperm functionality between the treated and 
control groups. After 14 days of treatment, each male rat was kept in a different cage together with two oestrous female rats. The rats were allowed to mate for seven days. Vaginal smears were performed to determine the gestation day. Pregnant female rats were later separated and kept for 16 days before sacrificed and the number of foetuses in the uterus was recorded (Chauhan \& Agarwal 2009).

\section{STATISTICAL ANALYSIS}

The data were expressed as mean \pm standard error of means (SEM). The statistical analysis was performed using oneway analysis of variance (ANOVA) with the value of $p<0.05$ was considered as statistically significant.

\section{RESULTS}

\section{FASTING BLOOD GLUCOSE LEVEL}

The effect of oral administration of GPAE for 14 days on the FBG level is shown in Figure 1. Based on the results, the administration of $450 \mathrm{mg} / \mathrm{kg}$ GPAE showed a significant reduction of FBG level $(6.7 \pm 0.65 \mathrm{mmol} / \mathrm{L})$ compared to other groups. The FBG level of negative control group was $23.9 \pm 2.22 \mathrm{mmol} / \mathrm{L}$. Even though the FBG level of the positive control group decreased $(13.5 \pm 2.98 \mathrm{mmol} / \mathrm{L})$, the level did not reach the normal blood glucose level.

\section{SPERM QUALITY}

The sperm quality data of all groups are displayed in Table 1. Daily administration of GPAE for 14 days showed that the overall sperm quality was significantly increased in Gynura procumbens treated group of $450 \mathrm{mg} / \mathrm{kg}$ as compared to the negative group. Gynura procumbens treated group of $150 \mathrm{mg} / \mathrm{kg}$ and $300 \mathrm{mg} / \mathrm{kg}$ showed recovery of sperm quality; however it was not significant as compared to the $450 \mathrm{mg} / \mathrm{kg}$ group.

\section{HORMONE TESTOSTERONE ANALYSIS}

The serum testosterone levels are shown in Figure 2. The testosterone level for treated rats with a dose of $450 \mathrm{mg} /$ $\mathrm{kg}$ seemed to increase to the normal testosterone level $(0.80 \pm 0.039 \mathrm{ng} / \mathrm{mL})$ compared to the negative and positive control groups. Based on the report by Turk et al. 2008, the normal testosterone level for a Sprague Dawley rat is $0.84 \pm 0.07 \mathrm{ng} / \mathrm{mL}$. These findings highlight the profertility activity of GPAE on male rat's reproductive system.

\section{SEXUAL BEHAVIOUR TEST}

The mounting frequency increased significantly in the treated groups compared to the negative and positive control groups. However, there was no significant difference of mounting frequency between all Gynura

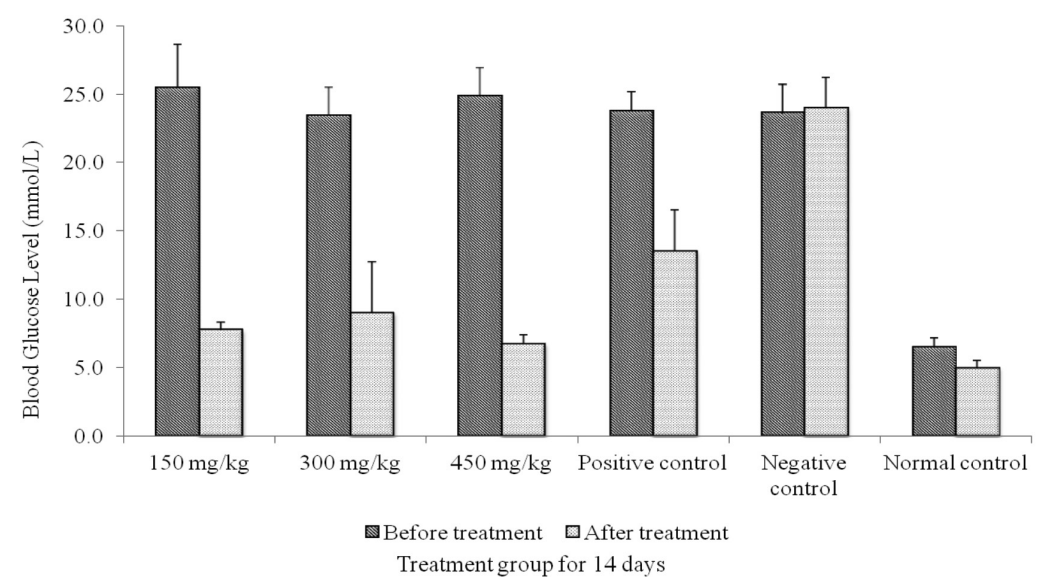

FIGURE 1. The effect of GPAE on blood glucose level after 14 days of treatment

TABLE 1 . The effect of GPAE on sperm quality after 14 days of treatment

\begin{tabular}{|c|c|c|c|c|c|c|}
\hline \multirow{2}{*}{ Group } & \multirow{2}{*}{$\begin{array}{l}\text { Sperm count } \\
\left(\times 10^{6}\right)\end{array}$} & \multirow{2}{*}{ Viability (\%) } & \multirow{2}{*}{$\begin{array}{l}\text { Normal morphology } \\
\text { (\%) }\end{array}$} & \multicolumn{3}{|c|}{ Motility (\%) } \\
\hline & & & & Progressive & Non-progressive & Immotile \\
\hline Normal & $37.27 \pm 0.61 *$ & $75.30 \pm 2.55^{*}$ & $87.86 \pm 1.66^{*}$ & $44.80 \pm 3.59 *$ & $30.49 \pm 5.05$ & $24.70 \pm 2.55$ \\
\hline Positive & $23.97 \pm 2.09$ & $57.88 \pm 2.45$ & $79.74 \pm 4.52 *$ & $32.84 \pm 3.16$ & $25.05 \pm 3.62$ & $42.12 \pm 2.45$ \\
\hline Negative & $22.88 \pm 4.52$ & $43.20 \pm 9.77$ & $71.60 \pm 2.58$ & $28.90 \pm 6.03$ & $28.63 \pm 6.78$ & $42.47 \pm 10.90$ \\
\hline $150 \mathrm{mg} / \mathrm{kg} \mathrm{GP}$ & $34.98 \pm 5.82 *$ & $65.82 \pm 11.56^{*}$ & $87.76 \pm 1.16 *$ & $41.48 \pm 1.24 *$ & $24.55 \pm 5.05$ & $33.97 \pm 11.55$ \\
\hline $300 \mathrm{mg} / \mathrm{kg} \mathrm{GP}$ & $39.02 \pm 2.30 *$ & $79.23 \pm 2.69 *$ & $84.82 \pm 2.38 *$ & $44.80 \pm 1.24 *$ & $34.64 \pm 2.09$ & $20.56 \pm 2.50 *$ \\
\hline $450 \mathrm{mg} / \mathrm{kg} \mathrm{GP}$ & $40.86 \pm 0.98^{*}$ & $78.18 \pm 1.88^{*}$ & $81.64 \pm 2.60 *$ & $46.98 \pm 0.81 *$ & $31.20 \pm 1.50$ & $21.82 \pm 1.88^{*}$ \\
\hline
\end{tabular}

*Significant difference compared to the diabetic group $(p<0.05)$ 


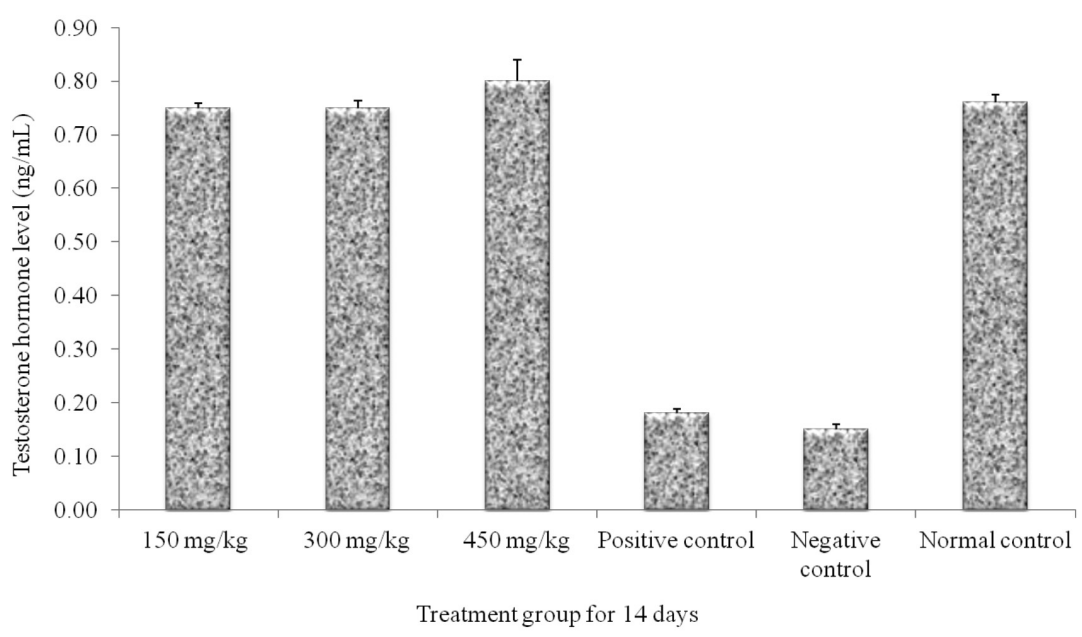

FIGURE 2. The effect of GPAE on testosterone hormone level after 14 days of treatment

procumbens treated groups. The Gynura procumbens treated group with a dose of $450 \mathrm{mg} / \mathrm{kg}$ showed a significant time length of mounting latency, $5.00 \pm 0.31 \mathrm{~min}$ and $13.86 \pm 0.34$ times of mounting frequency as compared to the negative and positive control groups. The results are displayed in Table 2 .

\section{FERTILITY TEST}

The results for fertility test are shown in Table 3. Based on the results obtained, the number of foetuses produced in the negative and positive control groups declined to $0 \pm 0.29$ and $3 \pm 1.10$, respectively compared to the control normal group (10 \pm 0.62$)$. Recovery and sperm functionality of all Gynura procumbens treated groups were observed.
A significant number of foetuses were produced compared to the negative and positive control groups.

\section{DISCUSSION}

Diabetes mellitus has been often associated with infertility problems such as erectile dysfunction and low sexual arousal (Adaikan et al. 2011). William and Pickup (2004) reported that about $90 \%$ of diabetes mellitus patients are of male at reproductive age. Glucose plays an important role in sperm development since glucose provides the nutrients required as well as energy in supporting sperm maturation and motility. Mita and Hall (1982) reported that glucose is important for the Sertoli

TABLE 2. The effect of GPAE on sexual behaviour after 14 days of treatment

\begin{tabular}{lcc}
\hline Group & Mounting frequency & Mounting latency (min) \\
\hline Normal & $9.29 \pm 0.29^{*}$ & $4.57 \pm 0.20^{*}$ \\
Positive & $3.57 \pm 0.30^{*}$ & $10.14 \pm 0.24^{*}$ \\
Negative & $0.71 \pm 0.18$ & $13.43 \pm 0.47$ \\
$150 \mathrm{mg} / \mathrm{kg} \mathrm{GP}$ & $9.29 \pm 0.18^{*}$ & $7.00 \pm 0.49^{*}$ \\
$300 \mathrm{mg} / \mathrm{kg} \mathrm{GP}$ & $9.86 \pm 0.26^{*}$ & $6.57 \pm 0.30^{*}$ \\
$450 \mathrm{mg} / \mathrm{kg} \mathrm{GP}$ & $13.86 \pm 0.34^{*}$ & $5.00 \pm 0.31^{*}$ \\
\hline
\end{tabular}

*Significant difference compared to the diabetic group $(p<0.05)$

TABLE 3. The effect of GPAE on fertility after 14 days of treatment

\begin{tabular}{lc}
\hline Group & Number of foetuses \\
\hline Normal & $10 \pm 0.62^{*}$ \\
Positive & $3 \pm 1.10^{*}$ \\
Negative & $0 \pm 0.29$ \\
$150 \mathrm{mg} / \mathrm{kg} \mathrm{GP}$ & $7 \pm 0.49 *$ \\
$300 \mathrm{mg} / \mathrm{kg} \mathrm{GP}$ & $7 \pm 0.36^{*}$ \\
$450 \mathrm{mg} / \mathrm{kg} \mathrm{GP}$ & $11 \pm 0.57^{*}$ \\
\hline
\end{tabular}

*Significant difference compared to the diabetic group $(p<0.05)$ 
cells to produce lactate and pyruvate through glycolisis for the spermatids. Glucose enters the Sertoli cells through passive transportation of blood-testes barriers (BTB). The BTB is a structure in the testes that consists of Sertoli cells and tight junctions which separate the interstitial spaces and seminiferous tubules (Alves et al. 2013a, 2013b). In the metabolism of glucose process in the testes, glucose is transported into the Sertoli cells via glucose transporter (GLUT). GLUT 1 and GLUT 3 are responsible for glucose uptake in lactate production. According to Oonk and Grootegoed (1987), there is an insulin-specific receptor in the Sertoli cells. This confirms that insulin is involved in the transportation of glucose into the Sertoli cells. Regulation of insulin in glucose metabolism in the Sertoli cells plays a crucial role in producing normal sperm in the testes. However, failure of insulin secretion may affect the glucose uptake in the testes.

The induction of streptozotocin (STZ) resulted in a significant increase of blood glucose level in the induced male rats. A study by Akbarzadeh et al. (2007) reported that the glucose level of STZ-induced male rats significantly elevated after four days of induction. Swelling was found occurred in the pancreas, where the $\beta$-cells of the islet of Langerhans were terribly degenerated. Hence, insulin could not be secreted and thus resulted in high blood glucose level.

Daily oral administration of GPAE for 14 consecutive days significantly reduced the FBG level and increased the fertility and libido of diabetic-induced male rats. Based on the results, the FBG level of each treated group was reduced significantly and the fertility of STZ-induced male rats was restored simultaneously up to a normal state compared to the untreated group. Zurina et al. (2010) reported that GPAE has the ability to mimic or increase insulin activity at cellular level. The study showed that the GPAE administration has resulted in high glucose uptake in the abdominal muscle of STZ-induced male rats compared to the control group. Therefore, GPAE is proven to have the ability to reduce blood glucose level by elevating the glucose uptake level at the skeletal muscle.

In this study, the sperm quality was analyzed based on these parameters: Number of sperm count, percentage of sperm motility, viability and morphology. Oral gavage treatment of GPAE showed significant increase of the sperm quality parameters compared to the untreated group. Rosidah et al. (2009) conducted a study using highperformance thin-layer chromatography (HPTLC) to find out the bioactive components in the Gynura procumbens extract and the results showed that Gynura procumbens extract contains several bioactive components including kaempferol, quercetin, rutinoside and astragalin which have the benefits for reproductive health specifically as an antioxidant.

Testes contains antioxidant enzymes and free radical scavenger to allow spermatogenesis and steroidogenic process so it can function normally and unaffected by oxidative stress. High production of reactive oxygen species (ROS) affects the oxidative condition in the testes as well as the sperm quality (Pusparanee et al. 2008). This is supported by numerous experimental evidence which emphasize the relationship between oxidative damage in testes or sperm and testicular dysfunction leading to male infertility (Shrilata \& Muralidhara 2007). Sperm cells consist of high polyunsaturated fatty acid (PUFA) which makes the plasma membrane of the sperm vulnerable to ROS (Alvarez \& Storey 1995). Hence, antioxidant is needed to protect the sperm from ROS and oxidative stress.

Quercetin is known to have the protective effect on sperm. It is an antioxidant that can be found in many plants. Isolated quercetin has been reported able to increase male fertility by increasing the sexual behaviour as well as sperm quality (Ladachart et al. 2008). In another study, the administration of isolated quercetin for 14 days in diabetic-induced male rats significantly increased the sperm quality (Khaki et al. 2009). Rutin was also found in Gynura procumbens extract. This bioflavonoid has been claimed to have the spermatogenesis protective effect by increasing the level of superoxide dismutase (SOD). SOD enzyme is important in catalyzing the anion superoxide to hydrogen peroxide (Butchi Akondi et al. 2011). The production of hydrogen peroxide helps in reducing the production of toxic hydroxyl radical. Both flavonoids have been claimed to show protective effects on male reproductive organ (testes) by reducing the oxidative stress (Khaki et al. 2009).

Metformin is categorized as a biguanide antidiabetic drug and it has been widely used due to its ability to reduce blood glucose level other than being cost-effective and safe. Metformin acts as an insulin sensitizer by activating the adenosine monophosphate kinase enzyme (AMP) which plays a part in carbohydrate and lipid metabolism. AMP inhibits mitochondria respiration that forces the hepatic glucose production to be inhibited. Hence, metformin increases the glucose uptake in the muscle, increases the oxidation of fatty acid, reduces lypolisis and stimulates insulin sensitivity towards glucose without producing hypoglycaemia (Gaochao et al. 2001). However, according to Tartarin et al. (2012), the administration of metformin in diabetic-induced male rats significantly decreased the level of testosterone hormone, reduced the testicle size and caused degeneration of Sertoli cells. The degeneration of Sertoli cells can be due to the reduction of proliferative cells compared to the dead cells (Alvez et al. 2014). This finding proved that metformin alters the physiological function of Sertoli cells and eventually leads to sperm of low quality.

The treatment of metformin on STZ-induced male rats for 14 days showed that the FBG level of the rats decreased. However, it was not significant and did not reach the normal blood glucose level. Based on the results obtained, metformin treated group showed a low number of sperm count, motility, morphology and viability. Thus, suggests that metformin is not able to reduce the FBG level to a normal blood glucose level within 14 days of treatment. The results also showed that metformin does not have any involvement in sperm quality and fertility recovery. 
The morphology and physiology of reproductive organ are maintained by hormone regulation, especially the testosterone hormone in male. Reduction or elevation of testosterone might affect spermatogenesis, cellular structures and other male reproductive functions. Hypothalamus is the control centre that secretes gonadotropin-releasing hormone $(\mathrm{GnRH})$ to stimulate pituitary gland to secrete luteinizing hormone (LH) and follicle-stimulating hormone (FSH). LH stimulates Leydig cells to produce testosterone hormone while FSH stimulates Sertoli cells to control cell proliferation during sperm maturation (Alves et al. 2013c).

Based on the results obtained in this study, the testosterone level in the treated group elevated after 14 days of treatment compared to the negative and positive control groups. Testosterone hormone plays an important role in maintaining the function of male reproductive system. Thus, the elevation of testosterone level increased the fertility of diabetic-induced male rats.

The results obtained also demonstrated that daily consumption of GPAE for 14 days significantly increased the mounting frequency of the treated groups compared to the untreated diabetic group. This suggests that Gynura procumbens extract affects male sexual behaviour through hormone regulation. This is also supported by Gupta et al. (2013) who claimed that male sexual behaviour is influenced by testosterone level.

The results of fertility test showed that the treated groups have a higher amount of foetuses compared to the untreated diabetic group. The administration of $450 \mathrm{mg} / \mathrm{kg}$ GPAE significantly increased the number of foetuses. This increment may be due to the elevation of sperm count and motility. Successful fertilization occurs when sufficient sperm concentration and motile sperm able to penetrate the cervical mucus (Gupta et al. 2006).

Although the antidiabetic mechanism of Gynura procumbens and the profertility effects are still unknown, it has been suggested that Gynura procumbens possesses the ability of regenerating spermatogenesis by acting on the Leydig and Sertoli cells as well as improving hormone secretion.

In conclusion, it is proven that GPAE has the potential to be used as plant-based antidiabetic, profertility and libido agents for diabetic patients. The mechanism of Gynura procumbens action towards diabetes, fertility, as well as libido effects can be studied further in the future.

\section{REFERENCES}

Adaikan, P.G. 2011. Abstract 17. Decline in testosterone: Relationship to libido and sexual dysfunction. Journal of Men's Health 8(Suppl. 1): S103.

Agmo, A. 1997. Protocol male rat sexual behaviour. Brain Research Protocols 1: 203-209.

Akowuah, G.A., Sadikun, A. \& Mariam, A. 2002. Flavonoid identification and hypo-glycemic studies of butanol fraction from Gynura procumbens. Pharmaceutical Biology 40: 405-410.

Akbarzadeh, A., Norouzian, D., Mehrabi, M.R., Jamshidi, Sh., Farhangi, A., Allah Verdi, A., Mofidian, S.M.A. \& Lame
Rad, B. 2007. Induction of diabetes by Streptozotocin in rats. Indian Journal of Clinical Biochemistry 22(2): 60-64.

Algariri, K., Meng, K.Y., Atangwho, I.J., Asmawi, M.Z., Sadikun, A., Murugiyah, V. \& Ismail, N. 2013. Hypoglycemic and antihyperglycemic study of Gynura procumbens leaf extracts. Asian Pacific Journal of Tropical Biomedicine 3(5): 358-366.

Alvarez, J.G. \& Storey, B.T. 1995. Differential incorporation of fatty acids into and peroxidative loss of fatty acids from phospholipids of human spermatozoa. Molecular Reproduction and Development 42: 334-346.

Alvez, M.G., Martins, A.D., Vaz, C.V., Correia, S., Moreira, P.I., Oliveira, P.F. \& Socorro, S. 2014. Metformin and male reproduction: Effects on Sertoli cells metabolism. British Journal of Pharmacology 171: 1032-1042

Alvez, M.G., Martins, A.D., Caraco, J.E., Socorro, S. \& Oliveira, P.F. 2013a. Molecular mechanisms beyond glucose transport in diabetes-related male infertility. Biochimica et Biophysica Acta 1832: 626-635.

Alvez, M.G., Martins, A.D., Caraco, J.E., Socorro, S. \& Oliveira, P.F. 2013b. Diabetes, insulin mediated glucose metabolism and Sertoli/blood-testes barrier function. Tissue Barriers 1: $1-12$.

Alvez, M.G., Rato, L., Carvaiho, R.A., Moreira, P.I., Socorro, S. \& Oliveira, P.F. 2013c. Hormonal control of Sertoli cells metabolism regulates spermatogenesis. Cellular and Molecular Life Sciences 70: 777-793.

Biggers, J.D., Whitten, W.K. \& Whittingham, D.G. 1971. The culture of mouse embryos in vitro. In Methods in Mammalian Embryology, edited by Daniel Jr., J.C. San Francisco: W.H. Freeman. pp. 86-116.

Butchi Akondi, R., Kumar, P., Annapurna, A. \& Pujari, M. 2011. Protective effect of rutin and naringin on sperm quality in streptozotocin (STZ) induced type I diabetic rats. Iranian Journal of Pharmaceutical Research 10(3): 585-596.

Chauhan,A. \& Agarwal, M. 2009. Assessment of the contraceptive efficacy of the aqueous extract of Aegel marmelos Corr. leaves in the male albino rats. Human Fertility 12: 107-118.

Gaochao, Z., Myers, R., Ying, L., Chen, Y., Xiaolan, S., Judy, F.M., Margaret, W., John, V., Thomas, D., Nobuharu, F., Nicalso, M., Michael, F.H., Laurie, J.G. \& David, E.M. 2001. Role of AMP-activated protein kinase in mechanism of metformin action. The Journal of Clinical Investigation 108: 1167-1174.

Gupta, A.K., Bindal, M.C., Gupta, S.K., Prakash, D.B. \& Vedpal. 2013. Aphrodisiac activity of Semecarpus anacordium nut. International Research Journal of Pharmacy 4(4): 202-204.

Gupta, R.S., Kachhawa, J.B.S., Khushalani, V., Tanuar, K. \& Joshi, Y.C. 2006. Effect of Cressa cretica methanol extract on testicular function of albino rats. Pharmaceuticals Biology 44: 382-388.

Khaki, A., Nouri, M., Fathiazad, F., Ahmadi-Ashtiani, H.R., Rastgar, H. \& Rezazadeh, S. 2009. Protective effects of quercetin on spermatogenesis in streptozotocin-induced diabetic rats. Journal of Medicinal Plants 5(8): 57-64.

Ladachart, T., Prakong, T., Noppadon, K. \& Suchinda, M. 2008. Stimulating effects of quercetin on sperm quality and reproductive organs in adult male rats. Asian Journal of Andrology 10: 249-258.

Mahanem Mat Noor \& Nani Rahayu. 2012. Anti-hyperglycemic effect of Gynura procumbens methanolic extract on fertility and libido of induced diabetic male rats. Sains Malaysiana 41(12): 1549-1556. 
Mita, M. \& Hall, F. 1982. Metabolism of round spermatids from rats: Lactate as the preferred substrate. Biology of Reproduction 26(3): 445-455.

Oonk, R.B. \& Grootegoed, J.A. 1987. Identification of insulin receptors on rat Sertoli cells. Molecular and Cellular Endocrinology 1(49): 51-62.

Perry, L.M. 1980. Medicinal Plants of East and Southeast Asia: Attributed Properties and Uses. Cambridge: The MIT Press. p. 94.

Pusparanee, H., Halimah A.S. \& Mahanem, M.N. 2008. Effects of Gynura procumbens extract and glibenclamide on sperm quality and specific activity of testicular lactate dehydrogenase in streptozotocin-induced diabetic rats. Malaysian Journal of Biochemistry and Molecular Biology 16(2): 10-14.

Rosidah, Mun, F.Y., Amirin, S., Mariam, A., Gabriel, A.A \& Mohd Zaini Asmawi. 2009. Toxicology evaluation of standardized methanol extract of Gynura procumbens. Journal of Ethnopharmacology 123: 244-249.

Shrilata, B. \& Muralidhara. 2007. Early oxidative stress in testes and epidydimal sperm in streptozotocin-induced diabetic mice: Its progression and genotoxic consequences. J. Reproductive Toxicology 23(4): 578-587.

Tartarin, P., Moison, D., Guilbert, E., Dupont, J., Hebert, R., Rouiller-Fabre, V., Frydman, N., Pozzi, S., Frydman, R., Lecureuil, C. \& Froment, P. 2012. Metformin exposure effects human and mouse fetal testicular cells. Human Reproduction 27(11): 3304-3314.
Turk, G., Sonmez, M., Aydin, M., Yuce, A. \& Aksoy, H. 2008. Effects of promegranate juice consumption on sperm quality, spermatogenic cell density, antioxidant activity and testosterone level in male rats. Clinical Nutrition 27: 289-296.

William, G. \& Pickup, J. 2004. Handbook of Diabetes Massachusettes: Blakewell Publishing.

World Health Organisation. 2010. Laboratory Manual for the Examination and Processing of Human Semen. Geneva: WHO Press.

Zurina Hassan, Mun Fei Yam, Mariam Ahmad \& Ahmad Pauzi M. Yusof. 2010. Antidiabteic properties and mechanisms of action of Gynura procumbens water extract in streptozotocininduced diabetic rats. Molecules 15: 9008-9023.

School of Biosciences and Biotechnology

Faculty of Science and Technology

Universiti Kebangsaan Malaysia

43600 UKM Bangi, Selangor Darul Ehsan

Malaysia

*Corresponding author; email: mahanem@ukm.edu.my

Received: 31 August 2016

Accepted: 1 April 2017 